University of Nebraska - Lincoln

DigitalCommons@University of Nebraska - Lincoln

2006

\title{
Benchmarking carcass characteristics and muscles from commercially identified beef and dairy cull cow carcasses for Warner-Bratzler shear force and sensory attributes
}

\author{
A. M. Stelzleni \\ University of Florida \\ L. E. Patten \\ University of Nebraska-Lincoln \\ D. D. Johnson \\ University of Florida, Gainesville \\ Chris R. Calkins \\ University of Nebraska-Lincoln, ccalkins1@unl.edu \\ B. L. Gwartney \\ National Cattlemen's Beef Association, Englewood, CO
}

Follow this and additional works at: https://digitalcommons.unl.edu/animalscifacpub

Part of the Animal Sciences Commons

Stelzleni, A. M.; Patten, L. E.; Johnson, D. D.; Calkins, Chris R.; and Gwartney, B. L., "Benchmarking carcass characteristics and muscles from commercially identified beef and dairy cull cow carcasses for WarnerBratzler shear force and sensory attributes" (2006). Faculty Papers and Publications in Animal Science. 564.

https://digitalcommons.unl.edu/animalscifacpub/564

This Article is brought to you for free and open access by the Animal Science Department at DigitalCommons@University of Nebraska - Lincoln. It has been accepted for inclusion in Faculty Papers and Publications in Animal Science by an authorized administrator of DigitalCommons@University of Nebraska - Lincoln. 


\title{
Benchmarking carcass characteristics and muscles from commercially identified beef and dairy cull cow carcasses for Warner-Bratzler shear force and sensory attributes ${ }^{1}$
}

\author{
A. M. Stelzleni, ${ }^{* 2}$ L. E. Patten, $\dagger$ D. D. Johnson, ${ }^{*}$ C. R. Calkins, $\uparrow$ and B. L. Gwartney \\ *Department of Animal Sciences, University of Florida, Gainesville 32611; †Department of Animal Science, \\ University of Nebraska, Lincoln 68583; and $\$$ National Cattlemen’s Beef Association, Englewood, CO 80155
}

\begin{abstract}
The objective of this study was to benchmark carcasses and muscles from commercially identified fed (animals that were perceived to have been fed an increased plane of nutrition before slaughter) and nonfed cull beef and dairy cows and A-maturity, USDA Select steers, so that the muscles could be identified from cull cow carcasses that may be used to fill a void of intermediately priced beef steaks. Carcass characteristics were measured at $24 \mathrm{~h}$ postmortem for 75 carcasses from 5 populations consisting of cull beef cows commercially identified as fed (B-F, $\mathrm{n}=15)$; cull beef cows commercially identified as nonfed (B-NF, $\mathrm{n}=15$ ); cull dairy cows commercially identified as fed (D-F, n = 15); cull dairy cows commercially identified as nonfed (D-NF, $\mathrm{n}=15$ ); and A-maturity, USDA Select grade steers (SEL, $n=15$ ). Nine muscles were excised from each carcass $[\mathrm{m}$. infraspinatus, $\mathrm{m}$. triceps brachii (lateral and long heads), m. teres major, m. longissimus dorsi (also termed LM), m. psoas major, m. gluteus medius, $\mathrm{m}$. rectus femoris, and $\mathrm{m}$. tensor fasciae latae] and subjected to Warner-Bratzler shear force testing and objective sensory panel evaluation after $14 \mathrm{~d}$ of postmortem aging. Carcass characteristics differed ( $P$ $<0.05$ ) among the 5 commercially identified slaughter
\end{abstract}

groups for the traits of lean maturity, bone maturity, muscle score, $\mathrm{HCW}$, fat color, subjective lean color, marbling, ribeye area, 12th-rib fat thickness, and preliminary yield grade. Carcasses from commercially identified, fed cull cows exhibited more $(P<0.01)$ weight in carcass lean than did commercially identified, nonfed cull cows. There was a group $\times$ muscle interaction $(P=$ 0.02) for Warner-Bratzler shear force. Warner-Bratzler shear force and sensory overall tenderness values demonstrates that muscles from the SEL group were the most tender $(P<0.01)$, whereas muscles from the B$\mathrm{NF}$ group were the least tender $(P<0.01)$. Sensory, beef flavor intensity was similar $(P>0.20)$ among cull cow carcass groups and more intense $(P<0.01)$ than the SEL carcass group. Muscles from the SEL group exhibited less $(P<0.01)$ detectable off-flavor than the cull cow carcass groups, whereas the B-NF group exhibited the most $(P<0.01)$ detectable off-flavor. Although carcass and muscle quality from commercially identified, fed, cull beef and dairy cows was not similar to Amaturity, USDA Select beef, they did show improvements when compared with nonfed, cull, beef and dairy cow carcasses and muscles.

Key words: cull cow, benchmarking, Warner-Bratzler, muscle

(C2007 American Society of Animal Science. All rights reserved.

J. Anim. Sci. 2007. 85:2631-2638

doi:10.2527/jas.2006-794

\section{INTRODUCTION}

Cows are culled for various reasons including age, poor performance, and failure to reproduce. Although cull cows are primarily a by-product of an industry dedicated to producing grain-fed, A-maturity beef (Cranwell et al., 1996a), they are still a valuable re-

\footnotetext{
${ }^{1}$ Funded in part by the Beef Checkoff.

${ }^{2}$ Corresponding author: astelz@uga.edu

Received December 4, 2006.

Accepted June 5, 2007.
}

source to producers and account for 15 to $20 \%$ of total revenues (Sawyer et al., 2004). As well, cull cows are equally important to the domestic beef supply. In 2004, approximately 5.1 million head of cull beef and dairy cows entered the slaughter market, accounting for almost $13 \%$ of domestically produced beef (USDA, 2005).

Several researchers have shown that increasing the nutritional plane of cull cows through supplementation before slaughter has improved carcass characteristics (Brown and Johnson, 1991) and tenderness (Miller et al., 1987). Short-term realimentation has also been shown to favorably impact carcass characteristics, tenderness, and sensory attributes (Matulis et al., 1987; 
Boleman et al., 1996; Cranwell et al., 1996a). However, most of current realimentation research focuses on the sensory attributes and tenderness of the longissimus dorsi (also termed LM), which along with the psoas major are commonly removed for further processing due to their increased value. Very little is known about muscles from older maturity cow carcasses and how production practices may influence their palatability.

Cows are typically segregated before slaughter by plant personnel based upon perceived quality and cutability. Therefore, it was the objective of this research to benchmark the carcass characteristics, muscle tenderness, and sensory attributes of commercially identified fed and nonfed beef and dairy cull cow carcasses and to compare them with USDA Select A-maturity beef. It was hypothesized that commercially identified fed beef and dairy cull cows would have a more desirable carcass and their muscles would have improved sensory characteristics when compared with commercially identified, nonfed cull cows, making them viable as an intermediately priced beef option.

\section{MATERIALS AND METHODS}

Animal Care and Use Committee approval was not obtained for this study because no live animals were used; rather, all samples were obtained from a federally inspected slaughter facility.

\section{Carcass Selection}

Seventy-five carcasses were selected randomly from 5 populations of slaughter cattle commercially identified by trained plant buyers and personnel as beef nonfed (B-NF), beef fed (B-F), dairy nonfed (D-NF), dairy fed (D-F), and concentrate fed A-maturity USDA Select (SEL) steers ( $\mathrm{n}=15$ each group) from Packerland Packing (Smithfield Beef Group, Green Bay, WI) on 2 sampling dates. Packerland Packing was chosen to source the cattle and carcasses due to their slaughtering and processing of all 5 treatment groups included in the current study. Cows commercially identified as nonfed were cows that were perceived to be fed maintenance diets without supplemental energy. Cows commercially identified as fed were those that were perceived by buyers and plant personnel to be fed supplemental energy before slaughter, based on their live condition. Animals of a particular slaughter type (B-NF, B-F, D-NF, D-F, or SEL) were assigned lot numbers, which, along with animal identification data, were made available to University of Florida and University of Nebraska personnel making proper selection possible.

For inclusion in the study, carcasses were visually selected that expressed no less than $2.54 \mathrm{~mm}$ of backfat and no less than medium-low muscle scores, based on the O-carcass conformation designation of EUROP (MLC, 2002), by University of Florida (Gainesville, FL) and University of Nebraska (Lincoln, NE) personnel. Carcasses that had missing muscles were not consid- ered for inclusion in the study. Upon selection, carcasses were ribbed between the 12th- to 13 th-rib junction and allowed to bloom for approximately $30 \mathrm{~min}$. After blooming, the carcass data were collected, including HCW, ribeye area (REA), 12th-rib fat thickness over the ribeye (FOE), preliminary yield grade (PYG), lean maturity (LMAT), bone maturity (BM), subjective lean color (LC), subjective fat color (FC), marbling score (MARB), and muscle score. Percent lean was calculated from carcass characteristics for all groups, and carcass composition was calculated by the ribbed carcass equations of Johnson and Rogers (1997).

After a 24-h chill, designated carcasses were separated into primal cuts by trained plant personnel. Muscles of interest $(n=9)$ were then excised from the chuck, loin, and round from each side of the carcass, for a total of 1,350 muscles examined. Muscles excised included $\mathrm{m}$. infraspinatus (INF); m. triceps brachii-lateral head (LAT); m. triceps brachii-long head (LON) and $\mathrm{m}$. teres major (TEM) from the chuck; $m$. longissimus dorsi (LOD) and m. psoas major (PSO) from the loin; and $\mathrm{m}$. gluteus medius (GM), m. rectus femoris (REF), and m. tensor fasciae latae (TFL) from the sirloin and round. Muscles from each side were labeled, vacuumpackaged, and grouped. Muscles from 1 side were then shipped to the University of Nebraska (Lincoln, NE), and the muscles from the other side were shipped to the University of Florida Meats Processing Center (Gainesville, FL). Muscles that were shipped to the University of Nebraska were analyzed for objective color, expressible moisture, proximate composition (percent moisture, percent protein, percent fat, and percent ash), $\mathrm{pH}$, total pigment, heme iron, and collagen content (Mink, 2004). At the University of Florida Meats Processing Center, steaks were cut to 2.54-cm thickness across the grain from the caudal end of the muscle on d 14 postmortem. Steaks were then vacuum-packaged and stored at $2^{\circ} \mathrm{C}$ until further analysis.

\section{Warner-Bratzler Shear Force}

Steaks from each muscle designated for WarnerBratzler shear force (WBS) were thawed for $18 \mathrm{~h}$ at $4^{\circ} \mathrm{C}$. Steaks were then cooked on Farberware OpenHearth Broilers (Farberware Products, Nashville, TN) that were preheated for $20 \mathrm{~min}$. Steaks were turned once when the internal temperature reached $35^{\circ} \mathrm{C}$ and then were allowed to finish cooking until they reached an internal temperature of $71^{\circ} \mathrm{C}$ (AMSA, 1995). Internal temperatures were monitored by constantan thermocouples (Omega Engineering Inc., Stamford, CT) placed in the geometric center of each steak and recorded using a 1100 Labtech Notebook for Windows 1998 (Computer Boards Inc., Middleboro, MA). Steaks then were allowed to cool for $18 \mathrm{~h}$ at $4^{\circ} \mathrm{C}$. After cooling, 6 cores, $1.27-\mathrm{cm}$ diam. were removed parallel to the longitudinal orientation of the muscle fibers. Cores were sheared once perpendicular to the longitudinal orientation of the muscle fibers with a Warner-Bratzler 
shear head at a cross-head speed of $200 \mathrm{~mm} / \mathrm{min}$, attached to an Instron Universal Testing machine (Instron Corporation, Canton, MA).

\section{Sensory Attributes}

Steaks designated for sensory panel evaluation were handled and cooked to the same specifications as the WBS samples. Upon reaching $71^{\circ} \mathrm{C}$ internal temperature, steaks were served to panelists while still warm. Sensory panelists evaluated 5 to 6 samples, 2 sample cubes that were $1.27 \mathrm{~cm}^{3}$ per sample, served in warmed, covered containers twice daily in a positive pressure, ventilation room with lighting and cubicles designed for objective meat sensory panels. A 7 to 11 member sensory panel trained according to AMSA sensory evaluation guidelines (AMSA, 1995) evaluated each sample for 3 sensory attributes. The 3 evaluated sensory traits included overall tenderness $(1=$ extremely tough, $2=$ very tough, $3=$ moderately tough, $4=$ slightly tough, $5=$ slightly tender, $6=$ moderately tender, $7=$ very tender, and $8=$ extremely tender), and beef flavor intensity $(1=$ extremely bland, $2=$ very bland, $3=$ moderately bland, $4=$ slightly bland, $5=$ slightly intense, $6=$ moderately intense, $7=$ very intense, and $8=$ extremely intense), and off-flavor detection ( 1 = extreme off-flavor; $2=$ strong off-flavor; $3=$ moderate off-flavor; $4=$ slight off-flavor; 5 = threshold off-flavor; and $6=$ no off-flavor.

\section{Statistical Analysis}

The data for carcass characteristics were analyzed as a completely randomized design, with carcass as the experimental unit to determine if means for carcass characteristic differed among the 5 slaughter groups. Carcass was the experimental unit, and carcass nested in group was considered a random variable and was used as the error term to test the effects of sources of variation. The analysis of WBS and sensory attributes was conducted utilizing a split-plot design, where carcass was considered the whole plot and muscle was the subplot and the experimental unit. The core for WBS or the cube for sensory analysis was considered the observational unit. For split-plot analysis of WBS and sensory panel data, carcass nested within slaughter group was considered the random effect of the whole plot, and muscle $\times$ carcass nested within slaughter group was considered the random term for the subplot of muscle. The MIXED procedure (SAS Inst. Inc., Cary, NC) was used to test the completely randomized and split-plot models. Means were separated using the PDIFF option of LSMEANS due to missing values. Differences among means were considered significant at $\mathrm{a} \leq 0.05$.

\section{RESULTS AND DISCUSSION}

\section{Carcass Characteristics}

Carcass characteristics and carcass composition are summarized in Tables 1 and 2, respectively. Cull cow carcasses designated as B-NF had the lightest $\mathrm{HCW}$, whereas B-F $(P=0.15)$ and D-NF $(P=0.87)$ were similar to the SEL group. The D-F group had the heaviest $(P<$ $0.05) \mathrm{HCW}$. As well, D-F had the most predicted percent bone and more weight in bone and predicted carcass fat free lean (CFFL) than the other 4 groups (Table 2). The SEL group had the largest REA but was similar $(P=0.06)$ to $\mathrm{B}-\mathrm{F}$ followed by D-F, B-NF, and finally DNF. Beef fed carcasses had the most $(P<0.01)$ FOE which corresponded with the lowest PL, greatest percent fat, and more predicted carcass weight in fat than any other group which contributed to the highest $(P<$ $0.01)$ PYG. Select grade carcasses were intermediate in FOE, whereas B-NF, D-NF, and D-F exhibited the least FOE. Preliminary yield grade followed FOE measurements with B-NF, D-NF, and D-F all being similar and lower than B-F or SEL groups. Select grade carcasses had the heaviest muscling score, which was expected. However, the B-F group had increased $(P<$ $0.01)$ muscling when compared with the B-NF group, whereas D-NF and D-F were similar $(P=0.15)$ in muscling.

Feeding cull cows either a high energy (above maintenance) or low energy (at maintenance) diet, Miller et al. (1987) reported similar findings to those found in the current research. Cull beef cows fed a higher energy diet had heavier HCW and larger ribeye areas than the cows fed a low energy diet. As well, Miller et al. (1987) reported similar 12th-rib fat thickness $(15.5 \mathrm{~mm})$ and yield grade (3.4) as reported in the current research. Brown and Johnson (1991) reported increases in 12thrib fat thickness, REA, and HCW when cull cows were supplemented with ammoniated hay, citrus pulp, cane molasses, or cane molasses with cottonseed meal. However, differences were not observed for yield grade between the treatments.

When quality grade factors were considered, the SEL group had the most desirable carcasses. Because the other 4 groups were representations of cull cow populations, their maturities were great enough that they were only eligible for Commercial or lower quality grades. Beef not-fed carcasses numerically had the oldest maturity scores for BM and LMAT. Dairy nonfed carcasses were younger but similar $(P>0.23)$ to B-NF in bone and lean maturities. However, the B-F group was younger $(P<0.02)$ than the B-NF group in bone and LMAT. It has been widely reported that feeding a high-energy diet before slaughter can improve LMAT scores. Cranwell et al. (1996a) reported that LMAT scores decreased in cull beef cows as time on feed increased from 0 to $56 \mathrm{~d}$ on feed. Faulkner et al. (1989) noticed improvements in LMAT when cull cows were fed a concentrate diet for $42 \mathrm{~d}$ but did not see any further improvements. As well, within type of cattle, carcass MARB increased for the groups that were perceived to have been fed an increased plane of nutrition. Beef nonfed and D-NF carcasses were eligible for USDA Utility quality grade standards, whereas B-F and DF were eligible for USDA Commercial quality grade. 
Table 1. Least squares means for carcass characteristics

\begin{tabular}{|c|c|c|c|c|c|c|}
\hline \multirow[b]{2}{*}{ Trait $^{1}$} & \multicolumn{5}{|c|}{ Group $^{2}$} & \multirow[b]{2}{*}{ SEM } \\
\hline & B-NF & B-F & D-NF & $\mathrm{D}-\mathrm{F}$ & SEL & \\
\hline $\mathrm{HCW}, \mathrm{kg}$ & $302.5^{\mathrm{c}}$ & $377.4^{\mathrm{b}}$ & $354.4^{\mathrm{b}}$ & $406.5^{\mathrm{a}}$ & $356.6^{\mathrm{b}}$ & 10.25 \\
\hline $\mathrm{REA}, \mathrm{cm}^{2}$ & $71.6^{\mathrm{cd}}$ & $82.7^{\mathrm{ab}}$ & $68.1^{\mathrm{d}}$ & $79.3^{\mathrm{bc}}$ & $91.2^{\mathrm{a}}$ & 3.19 \\
\hline $\mathrm{FOE}, \mathrm{cm}$ & $0.68^{\mathrm{c}}$ & $1.6^{\mathrm{a}}$ & $0.58^{\mathrm{c}}$ & $0.75^{\mathrm{c}}$ & $1.03^{b}$ & 0.09 \\
\hline PYG & $2.7^{\mathrm{c}}$ & $3.6^{\mathrm{a}}$ & $2.6^{\mathrm{c}}$ & $2.7^{\mathrm{c}}$ & $3.0^{\mathrm{b}}$ & 0.09 \\
\hline Lean maturity ${ }^{3}$ & $440^{\mathrm{a}}$ & $374^{\mathrm{b}}$ & $423^{\mathrm{ab}}$ & $409^{\mathrm{ab}}$ & $142^{\mathrm{c}}$ & 18.05 \\
\hline Bone maturity ${ }^{3}$ & $507^{\mathrm{a}}$ & $437^{\mathrm{b}}$ & $433^{\mathrm{b}}$ & $472^{\mathrm{ab}}$ & $145^{\mathrm{c}}$ & 21.66 \\
\hline Lean color ${ }^{4}$ & $3.5^{\mathrm{c}}$ & $4.7^{\mathrm{b}}$ & $3.6^{\mathrm{c}}$ & $3.8^{\mathrm{c}}$ & $6.3^{\mathrm{a}}$ & 0.29 \\
\hline Fat color ${ }^{5}$ & $4.5^{\mathrm{a}}$ & $3.3^{\mathrm{c}}$ & $4.0^{\mathrm{b}}$ & $3.5^{\mathrm{c}}$ & $2.1^{\mathrm{d}}$ & 0.15 \\
\hline Marbling ${ }^{6}$ & $377^{\mathrm{cd}}$ & $509^{\mathrm{b}}$ & $450^{\mathrm{bc}}$ & $608^{\mathrm{a}}$ & $356^{\mathrm{d}}$ & 30.72 \\
\hline Muscle score $^{7}$ & $520^{\mathrm{c}}$ & $660^{\mathrm{b}}$ & $430^{\mathrm{d}}$ & $470^{\text {cd }}$ & $810^{\mathrm{a}}$ & 19.52 \\
\hline \multicolumn{7}{|c|}{ 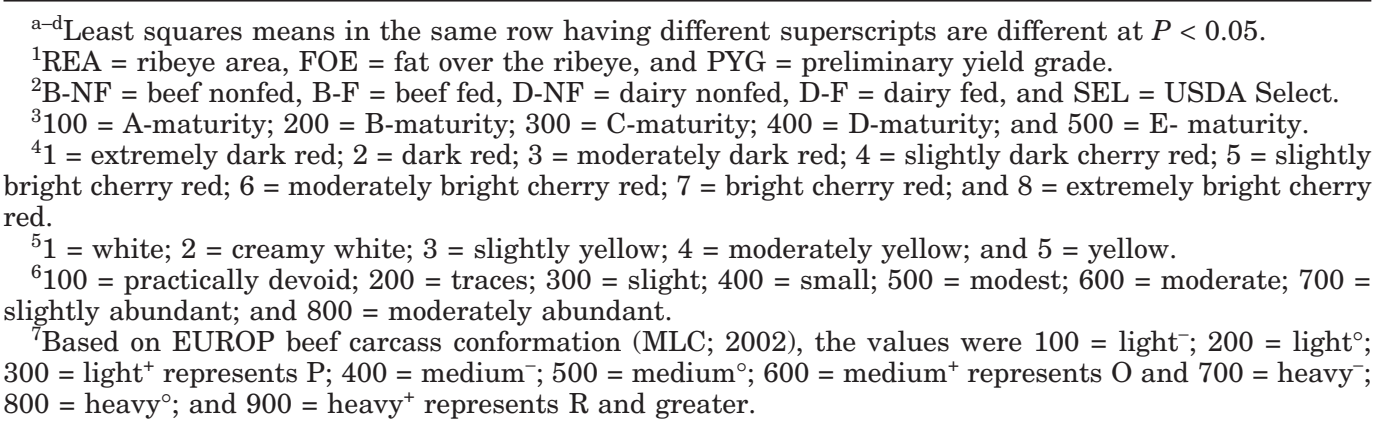 } \\
\hline
\end{tabular}

Although D-F had older maturity scores than B-F, D$\mathrm{F}$ also had greater $(P=0.03) \mathrm{MARB}$, whereas the lower LMAT of the B-F group help it to maintain a more desirable quality grade.

Select grade carcasses had the brightest lean after blooming and the whitest fat of all groups examined. Cull dairy cows commercially identified as being fed a high energy ration before slaughter were similar $(P=$ $0.62)$ in LC, but had whiter $(P=0.03)$ fat when compared with commercially identified, nonfed cull dairy cows. Cull beef cows commercially identified as fed had carcasses that were brighter in their lean $(P<0.01)$ and whiter in their fat $(P<0.01)$ than commercially identified, nonfed cull beef cows. Carcasses from nonfed beef cows were not different from D-NF $(P=0.74)$ and $\mathrm{D}-\mathrm{F}(P=0.41)$ in LC, but B-NF had the yellowest FC $(P<0.01)$ of all 5 groups researched. The yellow fat reported in the B-NF group could be attributed to increased carotene content that is deposited in the lipid tissues of animals when fed a forage-based diet that is high in carotene (Yang et al., 1992). Grains tend to have lower concentrations of carotenoids than forages (Strachan et al., 1993). Therefore, if the cull cows of the current study were fed high energy diets with grains in them, the lightening of fat could have been caused by a dilution effect of more fat being deposited with less carotene (French et al., 2000).

Feeding high-energy diets to cull cows before slaughter has the ability to improve the quality grade by 2 primary factors: LMAT scores tended to decrease and MARB tended to increase. Lean maturity scores could be improved by producing a brighter lean (Miller et al., 1987; Boleman et al., 1996; Cranwell et al., 1996a) and firmer, finer textured lean (Brown and Johnson, 1991).

Table 2. Least squares means for carcass composition

\begin{tabular}{lcccccc}
\hline \hline & \multicolumn{5}{c}{ Group $^{2}$} \\
\cline { 2 - 5 } Trait $^{1}$ & B-NF & B-F & D-NF & D-F & SEL & SEM \\
\hline CFFL, $^{3} \%$ & $64.1^{\mathrm{a}}$ & $58.5^{\mathrm{bc}}$ & $60.2^{\mathrm{b}}$ & $57.1^{\mathrm{c}}$ & $64.9^{\mathrm{a}}$ & 1.01 \\
Fat, $^{3} \%$ & $14.8^{\mathrm{c}}$ & $24.0^{\mathrm{a}}$ & $16.1^{\mathrm{c}}$ & $20.6^{\mathrm{b}}$ & $17.3^{\mathrm{c}}$ & 0.97 \\
Bone $^{3} \%$ & $16.0^{\mathrm{b}}$ & $12.1^{\mathrm{c}}$ & $18.0^{\mathrm{a}}$ & $16.5^{\mathrm{ab}}$ & $12.8^{\mathrm{c}}$ & 0.56 \\
CFFL, $^{4} \mathrm{~kg}$ & $199.3^{\mathrm{d}}$ & $226.9^{\mathrm{bc}}$ & $221.6^{\mathrm{c}}$ & $245.0^{\mathrm{a}}$ & $238.5^{\mathrm{ab}}$ & 5.80 \\
Fat, $^{4} \mathrm{~kg}$ & $45.7^{\mathrm{c}}$ & $95.2^{\mathrm{a}}$ & $60.7^{\mathrm{b}}$ & $89.0^{\mathrm{a}}$ & $63.7^{\mathrm{b}}$ & 4.81 \\
Bone, $^{\mathrm{a}} \mathrm{kg}$ & $49.8^{\mathrm{b}}$ & $47.23^{\mathrm{b}}$ & $66.9^{\mathrm{a}}$ & $70.7^{\mathrm{a}}$ & $46.9^{\mathrm{b}}$ & 2.88 \\
Lean $\%$ & $81.7^{\mathrm{a}}$ & $71.4^{\mathrm{c}}$ & $80.4^{\mathrm{a}}$ & $76.7^{\mathrm{b}}$ & $77.2^{\mathrm{b}}$ & 0.93 \\
\hline
\end{tabular}

${ }^{\mathrm{a}-\mathrm{d}}$ Least squares means in the same row having different superscripts are different at $P<0.05$.

${ }^{1} \mathrm{CFFL}=$ carcass fat free lean.

${ }^{2} \mathrm{~B}-\mathrm{NF}$ = beef nonfed; B-F = beef fed; D-NF = dairy nonfed; D-F = dairy fed; and SEL = USDA Select.

${ }^{3}$ Values calculated by using the equations of Johnson and Rogers (1997).

${ }^{4}$ Values calculated by multiplying percentage of carcass composition by HCW. 
A second factor affecting quality grades in cull cows has been shown to be an increased MARB associated with feeding a high-energy diet before slaughter (Matulis et al., 1987; Miller et al., 1987; Cranwell et al., 1996a). However, Sawyer et al. (2004) reported no differences in cull cow LC, FC, MARB, LMAT, and overall maturity when cows were fed conservatively (30\% roughage, $70 \%$ concentrate) or aggressively (decreasing roughage from 30 to $10 \%$, and increasing concentrate).

Select grade carcasses had similar $(P=0.57)$ predicted percent CFFL when compared with B-NF carcasses and similar percent carcass fat to B-NF $(P=0.08)$ and D-NF $(P=0.40)$ groups. However, D-F carcasses numerically had the most predicted CFFL weight of any group and numerically had the least percent CFFL. As stated previously, this is attributed to heavier HCW recorded for the D-F group. Dairy fed carcasses had the least $(P<0.05)$ predicted percent CFFL, and B-F carcasses had the second lowest percent CFFL. However, B-F carcasses had the most $(P<0.05)$ predicted percent fat, followed by D-F carcasses. Dairy type cull cow carcasses had the most predicted bone as a percent of the carcass followed by B-NF. Beef fed and SEL carcasses were similar $(P=0.39)$ in percent bone. As well, B-F and SEL carcasses were similar $(P=0.16)$ in CFFL weight, but the B-F group had more $(P<0.01)$ carcass weight in fat than B-NF, D-NF, or SEL groups. As expected, dairy type cull cows had more predicted carcass weight in bone than B-NF, B-F, and SEL, which were all similar $(P>0.05)$ in carcass bone weight.

Faulkner et al. (1989) and Cranwell et al. (1996b) reported that in realimented cull cows, percent carcass bone decreased with increasing time on concentrate feed and carcass soft tissue increased. However, soft tissues were not separated into lean and fat. Therefore, the increase in percent soft tissue may have been due to an increase in carcass fat because it was noted that 12th-rib fat thickness and yield grades also increased with time on feed. Matulis et al. (1987) found that carcass fat free lean and fat weight increased significantly the longer cull cows were on a concentrate diet before slaughter. The carcass fat free lean gained at a similar rate for all feeding periods $(0,28,56$, and $84 \mathrm{~d}$ on feed), whereas fat weight gained the most at $28 \mathrm{~d}$ on feed and then increased at a lower rate for each feeding period thereafter.

\section{Warner-Bratzler Shear Force}

The B-NF group was the least tender group for the GM $(P<0.02)$, INF $(P<0.02)$, LOD $(P<0.01)$, and TEM $(P<0.04)$ when examining WBS values (Table 3 ; group $\times$ muscle interactions, $P=0.02$ ), which led to the $\mathrm{B}-\mathrm{NF}$ group being the least tender group overall (Table $4, P$ $<0.01)$. Warner-Bratzler shear force was not different among B-F and D-NF $(P=0.73)$, B-F and D-F ( $P=$ $0.49)$, or D-NF and D-F groups $(P=0.73)$ for any muscles researched. The SEL group was significantly $(P<0.01)$ more tender than any of the other groups studied when comparing WBS values. It has been well documented that heat liable collagen content decreases with advancing age (Hill, 1966; Herring et al., 1967; Bailey and Shimokomaki, 1971), which would explain the differences noticed between SEL and the other 4 groups. Aberle et al. (1981) concluded feeding cattle high-energy diets would promote rapid rates of protein synthesis and produce beef with a high proportion of newly synthesized, heat liable collagen. Therefore, B-F and $\mathrm{D}-\mathrm{F}$ groups may have been more tender than the B-NF group due to increases in heat liable collagen that was gained during lean accretion, as evidenced by the increase in REA.

Examining muscles of the chuck (Table 3 ) it was noticed that INF had the smallest WBS value irrespective of group. For each muscle (INF, LAT, LON, and TEM), WBS values were lower for steaks from the B-F group than from the B-NF group. This difference was significant for the INF $(P=0.02)$ and TEM $(P<0.01)$. The INF, LAT, LON, and TEM were similar $(P>0.35)$ for $\mathrm{B}-\mathrm{F}, \mathrm{D}-\mathrm{NF}$, and D-F groups. However, the SEL group had lower $(P<0.04)$ WBS values for the INF, LAT, and LON when compared with the other 4 groups. The muscles from the chuck for cull beef cows that were affected the most by supplemental feeding before slaughter were the INF and the TEM.

The PSO was not different $(P>0.20)$ for any group. However, the LOD had significantly larger $(P<0.01)$ WBS values for the B-NF group when compared with B-F, D-NF, D-F, and SEL groups, which were similar $(P>0.37)$ to each other. The LOD was almost $2 \mathrm{~kg}$ less for WBS value between B-NF and B-F groups, which was the largest difference noted for a muscle between groups observed during this study. Most of the current literature examining cattle fed diets of differing energy levels focuses on the $\mathrm{m}$. longissimus dorsi. Boleman et al. (1996) reported that longissimus WBS values significantly decreased after cull cows were on a concentrate diet for 56 d, whereas Faulkner et al. (1989) reported a decrease in cull cow loin shear force after 42 d on feed. Cranwell et al. (1996a) also reported a decrease in loin shear force after $28 \mathrm{~d}$ on concentrate but did not observe any further decreases. In opposition to the current study, Brown and Johnson (1991) did not report a significant difference for longissimus WBS values when cull cows were fed hay or high-energy supplements before slaughter.

The GM had the greatest WBS value $(P<0.02)$ for the B-NF group, but was smaller and similar $(P>0.30)$ among the B-F, D-NF, and D-F groups. The GM WBS values were the lowest for the SEL group and were similar $(P=0.08)$ only to the D-F group. The REF WBS values were similar $(P>0.22)$ among the B-NF, B-F, $\mathrm{D}-\mathrm{NF}$, and D-F groups but were lower $(P>0.01)$ for the SEL group. However, the REF WBS scores were numerically lower for the B-F and D-F groups than for the B-NF and D-NF groups, respectively. The TFL was similar $(P>0.18)$ in WBS scores when the 4 cow groups were compared. The TFL from the SEL group was sig- 
Table 3. Least squares means ${ }^{1}$ of Warner-Bratzler ${ }^{2}$ shear force for the interaction of group $\times$ muscle

\begin{tabular}{|c|c|c|c|c|c|}
\hline \multirow[b]{2}{*}{ Muscle $^{4}$} & \multicolumn{5}{|c|}{ Group $^{3}$} \\
\hline & B-NF & B-F & D-NF & $\mathrm{D}-\mathrm{F}$ & SEL \\
\hline GM & $7.44^{\mathrm{a}, \mathrm{tu}}$ & $6.25^{\mathrm{b}, \mathrm{t}}$ & $6.30^{\mathrm{b}, \mathrm{t}}$ & $5.85^{\mathrm{bc}, \mathrm{t}}$ & $5.16^{\mathrm{c}, \mathrm{t}}$ \\
\hline INF & $4.88^{\mathrm{a}, \mathrm{y}}$ & $4.00^{\mathrm{b}, \mathrm{v}}$ & $3.77^{\mathrm{b}, \mathrm{w}}$ & $3.77^{\mathrm{b}, \mathrm{v}}$ & $2.96^{\mathrm{c}, \mathrm{x}}$ \\
\hline LAT & $5.71^{\mathrm{a}, \mathrm{wx}}$ & $5.65^{\mathrm{a}, \mathrm{tu}}$ & $5.34^{\mathrm{a}, \mathrm{tuv}}$ & $5.66^{\mathrm{a}, \mathrm{t}}$ & $4.42^{\mathrm{b}, \mathrm{uv}}$ \\
\hline LOD & $7.58^{\mathrm{a}, \mathrm{t}}$ & $5.68^{\mathrm{b}, \mathrm{tu}}$ & $5.82^{\mathrm{b}, \mathrm{tu}}$ & $5.99^{\mathrm{b}, \mathrm{t}}$ & $5.33^{\mathrm{b}, \mathrm{t}}$ \\
\hline $\mathrm{LON}$ & $6.81^{\text {a,tuv }}$ & $6.14^{\mathrm{ab}, \mathrm{t}}$ & $5.94^{\mathrm{b}, \mathrm{tu}}$ & $5.89^{\mathrm{b}, \mathrm{t}}$ & $4.65^{\mathrm{c}, \mathrm{tuv}}$ \\
\hline PSO & $3.93^{\mathrm{a}, \mathrm{z}}$ & $4.02^{\mathrm{a}, \mathrm{v}}$ & $3.94^{\mathrm{a}, \mathrm{w}}$ & $3.52^{\mathrm{a}, \mathrm{v}}$ & $3.62^{\mathrm{a}, \mathrm{wx}}$ \\
\hline $\mathrm{REF}$ & $6.24^{\mathrm{a}, \mathrm{vw}}$ & $5.76^{\mathrm{a}, \mathrm{tu}}$ & $6.03^{\mathrm{a}, \mathrm{tu}}$ & $5.79^{\mathrm{a}, \mathrm{t}}$ & $4.76^{\mathrm{b}, \mathrm{tuv}}$ \\
\hline TEM & $6.65^{\mathrm{a}, \mathrm{v}}$ & $5.66^{\mathrm{b}, \mathrm{tu}}$ & $5.81^{\mathrm{b}, \mathrm{tu}}$ & $5.71^{\mathrm{b}, \mathrm{t}}$ & $5.09^{\mathrm{b}, \mathrm{tu}}$ \\
\hline TFL & $5.30^{\mathrm{a}, \mathrm{xy}}$ & $5.20^{\mathrm{a}, \mathrm{u}}$ & $4.77^{\mathrm{ab}, \mathrm{v}}$ & $4.93^{\mathrm{ab}, \mathrm{u}}$ & $4.16^{\mathrm{b}, \mathrm{vw}}$ \\
\hline
\end{tabular}

${ }^{\mathrm{a}-\mathrm{c}}$ Least squares means in the same row having different superscripts are different at $P<0.05$.

${ }^{\mathrm{t}-\mathrm{z}}$ Least squares means in the same column having different superscripts are different at $P<0.05$.

${ }^{1}$ Standard error of least squares means for all interactions $=0.28$.

${ }^{2}$ Warner-Bratzler shear force measurements are in kilograms.

${ }^{3} \mathrm{~B}-\mathrm{NF}$ = beef nonfed; B-F = beef fed; D-NF = dairy nonfed; D-F = dairy fed; and SEL = USDA Select.

${ }^{4} \mathrm{GM}$ = gluteus medius; INF = infraspinatus; LAT = triceps brachii-lateral head; LOD = longissimus dorsi; LON = triceps brachii-long head; $\mathrm{PSO}$ = psoas major; $\mathrm{REF}=$ rectus femoris; TEM = teres major; and TFL = tensor fasciae latae.

nificantly lower $(P<0.01)$ than the B-NF and B-F groups.

The GM, INF, LOD, and TEM from the B-NF group had larger $(P<0.05)$ WBS values than all other groups. The LAT, TFL, and REF from all cow groups were similar. In addition, the B-NF group was equivalent to the B-F group for WBS on the LON. There were no differences among any of the groups for the PSO. In contrast, INF, LAT, LON, and REF from the SEL group had lower $(P<0.05)$ WBS than any of the cow groups. Excluding the B-NF group, the LOD and TEM from SEL carcasses were similar in WBS to the cow groups. These data suggest meaningful differences exists in WBS between cow beef and USDA Select grade beef for 4 muscles (INF, LAT, LON, and REF), whereas similarities in WBS were evident for the LOD, PSO, and TEM.

The effects of muscle on WBS value (Table 3, group $\times$ muscle interaction, $P=0.02$; muscle main effects,
Table 5) showed that the GM was the least tender muscle examined but was similar to the LOD $(P=0.45)$ and LON $(P=0.06)$. The PSO had the lowest WBS value, making it the most tender muscle studied. However, the PSO was similar to the INF among the B-F, $\mathrm{D}-\mathrm{NF}$, and D-F groups $(P>0.48)$. The TFL was different $(P<0.01)$ from the PSO and INF, but it was the overall third most tender muscle found. Based on WBS values, LAT, LON, REF, and TEM showed promise as muscles that could be fabricated into steaks with intermediate tenderness, and the INF and TFL could be fabricated into steaks with a high tenderness rating.

\section{Sensory Attributes}

The means of group and muscle on sensory panel attributes are shown in Table 4 for carcass group and Table 5 for muscle. There was not a significant $(P>$

Table 4. Least squares means of Warner-Bratzler shear force and sensory attributes for the main effect of group

\begin{tabular}{|c|c|c|c|c|c|c|}
\hline \multirow[b]{2}{*}{ Trait } & \multicolumn{5}{|c|}{ Group $^{1}$} & \multirow[b]{2}{*}{ SEM } \\
\hline & $\mathrm{B}-\mathrm{NF}$ & $\mathrm{B}-\mathrm{F}$ & $\mathrm{D}-\mathrm{NF}$ & $\mathrm{D}-\mathrm{F}$ & SEL & \\
\hline Warner-Bratzler shear force, ${ }^{2} \mathrm{~kg}$ & $6.06^{\mathrm{a}}$ & $5.37^{\mathrm{b}}$ & $5.30^{\mathrm{b}}$ & $5.23^{\mathrm{b}}$ & $4.46^{\mathrm{c}}$ & 0.14 \\
\hline Overall tenderness ${ }^{3}$ & $4.4^{\mathrm{a}}$ & $4.9^{\mathrm{b}}$ & $4.8^{\mathrm{b}}$ & $4.9^{\mathrm{b}}$ & $5.6^{\mathrm{c}}$ & 0.09 \\
\hline Beef flavor intensity ${ }^{4}$ & $5.7^{\mathrm{a}}$ & $5.7^{\mathrm{a}}$ & $5.7^{\mathrm{a}}$ & $5.7^{\mathrm{a}}$ & $5.5^{\mathrm{b}}$ & 0.04 \\
\hline Off-flavor ${ }^{5}$ & $4.8^{\mathrm{a}}$ & $5.2^{\mathrm{b}}$ & $5.3^{\mathrm{b}}$ & $5.2^{\mathrm{b}}$ & $5.5^{\mathrm{c}}$ & 0.06 \\
\hline \multicolumn{7}{|c|}{$\begin{array}{l}{ }^{\mathrm{a}-\mathrm{c}} \text { Least squares means in the same row having different superscripts are different at } P<0.05 \text {. } \\
{ }^{1} \mathrm{~B}-\mathrm{NF}=\text { beef nonfed; } \mathrm{B}-\mathrm{F}=\text { beef fed; } \mathrm{D}-\mathrm{NF}=\text { dairy nonfed; } \mathrm{D}-\mathrm{F}=\text { dairy fed; and SEL = USDA Select. } \\
{ }^{2} \mathrm{~A} \text { group } \times \text { muscle interaction was observed for these data at } P=0.02 . \\
{ }^{3} 1=\text { extremely tough; } 2=\text { very tough; } 3=\text { moderately tough; } 4=\text { slightly tough; } 5=\text { slightly tender; } 6= \\
\text { moderately tender; } 7=\text { very tender; and } 8=\text { extremely tender. } \\
{ }^{4} 1=\text { extremely bland; } 2=\text { very bland; } 3=\text { moderately bland; } 4=\text { slightly bland; } 5=\text { slightly intense; } 6= \\
\text { moderately intense; } 7=\text { very intense; and } 8=\text { extremely intense. } \\
{ }^{5} 1=\text { extreme off-flavor; } 2=\text { strong off-flavor; } 3=\text { moderate off-flavor; } 4=\text { slight off-flavor; } 5=\text { threshold } \\
\text { off-flavor; and } 6=\text { no off-flavor. }\end{array}$} \\
\hline
\end{tabular}


Table 5. Least squares means of Warner-Bratzler shear force and sensory attribute for the main effect of muscle

\begin{tabular}{|c|c|c|c|c|c|c|c|c|c|c|}
\hline Trait & \multicolumn{9}{|c|}{ Muscle $^{1}$} & SEM \\
\hline Warner-Bratzler shear force ${ }^{2} \mathrm{~kg}$ & $6.20^{\mathrm{a}}$ & $3.88^{\mathrm{f}}$ & $5.36^{\mathrm{d}}$ & $6.08^{\mathrm{ab}}$ & $5.89^{\mathrm{abc}}$ & $3.81^{\mathrm{f}}$ & $5.72^{\mathrm{c}}$ & $5.78^{\mathrm{bc}}$ & $4.87^{\mathrm{e}}$ & 0.12 \\
\hline Overall tenderness ${ }^{3}$ & $4.1^{\mathrm{d}}$ & $5.1^{\mathrm{b}}$ & $4.7^{\mathrm{c}}$ & $4.7^{\mathrm{c}}$ & $4.9^{\mathrm{c}}$ & $5.6^{\mathrm{a}}$ & $4.8^{\mathrm{c}}$ & $5.5^{\mathrm{a}}$ & $4.7^{\mathrm{c}}$ & 0.08 \\
\hline Beef flavor intensity ${ }^{4}$ & $5.6^{\mathrm{a}}$ & $5.4^{\mathrm{b}}$ & $5.8^{\mathrm{a}}$ & $5.7^{\mathrm{a}}$ & $5.7^{\mathrm{a}}$ & $5.7^{\mathrm{a}}$ & $5.6^{\mathrm{a}}$ & $5.7^{\mathrm{a}}$ & $5.7^{\mathrm{a}}$ & 0.05 \\
\hline Off-flavor ${ }^{5}$ & $5.1^{\mathrm{cd}}$ & $5.2^{\mathrm{bc}}$ & $4.9^{\mathrm{d}}$ & $5.2^{\mathrm{bc}}$ & $5.3^{\mathrm{ab}}$ & $5.1^{\mathrm{cd}}$ & $5.4^{\mathrm{a}}$ & $5.2^{\mathrm{bc}}$ & $5.3^{\mathrm{a}}$ & 0.05 \\
\hline
\end{tabular}

${ }^{\mathrm{a}-\mathrm{f}}$ Least squares means in the same row having different superscripts are different at $P<0.05$.

${ }^{1} \mathrm{GM}=$ gluteus medius; INF = infraspinatus; LAT = triceps brachii-lateral head; LOD = longissimus dorsi; LON = triceps brachii-long head; PSO = psoas major; REF = rectus femoris; TEM = teres major; and TFL = tensor fasciae latae.

${ }^{2} \mathrm{~A}$ group $\times$ muscle interaction was observed for these data at $P=0.02$.

${ }^{3} 1$ = extremely tough; 2 = very tough; $3=$ moderately tough; $4=$ slightly tough; $5=$ slightly tender; $6=$ moderately tender; $7=$ very tender; and $8=$ extremely tender.

${ }^{4} 1$ = extremely bland; 2 = very bland; 3 = moderately bland; 4 = slightly bland; 5 = slightly intense; $6=$ moderately intense; $7=$ very intense; and $8=$ extremely intense.

${ }^{5} 1$ = extreme off-flavor; 2 = strong off-flavor; 3 = moderate off-flavor; 4 = slight off-flavor; $5=$ threshold off-flavor; and $6=$ no off-flavor.

$0.07)$ group $\times$ muscle interaction for the sensory attributes. The group main effect means for sensory overall tenderness followed the same trend as did carcass group main effect means for WBS values. The SEL carcass group was rated as being more tender $(P<0.01)$ than B-NF, B-F, D-NF, and D-F carcass groups. In agreement with the WBS results, B-NF was rated as being the least tender $(P<0.01)$ group, whereas B-F, D$\mathrm{NF}$, and D-F were similar $(P>0.94)$ for sensory overall tenderness. Boleman et al. (1996) and Cranwell et al. (1996a) both reported that realimented cull cows were rated as being more tender than cull cows that were not realimented. Boleman et al. (1996) concluded that as time on a high-energy diet increased, myofibrillar fragmentation became easier and detectable connective tissue decreased, therefore contributing to the improvement in overall tenderness. Conversely, several authors reported that feeding high-energy diets versus feeding low-energy diets to young steers had no significant effect on sensory overall tenderness (Bidner et al., 1985; Schaake et al., 1993). Similarly, Miller et al. (1987) reported no difference in loin sensory tenderness between cull cows fed a high-energy diet or a maintenance diet before slaughter. Dryden et al. (1979) reported no difference between fed and nonfed cull cows for the $\mathrm{m}$. semimembranosus and m. triceps brachii. However, the $\mathrm{m}$. gluteus medius and $\mathrm{m}$. biceps femoris both increased in sensory tenderness when cull cows were realimented.

There was no difference $(P>0.23)$ between cull cow groups for beef flavor intensity. However, the SEL group had lower $(P<0.02)$ beef flavor intensity score than the 4 cow groups, with a difference of 0.2 units on a scale that rated beef flavor intensity from 1 to 8 . The B-NF group had the strongest $(P<0.01)$ off-flavors detected, whereas the SEL group had the weakest $(P<$ 0.01 ) off-flavors detected. Muscles from cull cow groups had off-flavor scores ranging from 0.2 to 0.7 units from muscles that came from SEL carcasses. The B-F, D$\mathrm{NF}$, and D-F groups were similar $(P>0.58)$ in their scores for sensory off-flavor detection. Boleman et al. (1996) found that feeding cull cows a concentrate diet before slaughter increased beef intensity flavor by 56 $\mathrm{d}$ on feed and decreased off-flavor detection by $28 \mathrm{~d}$ on feed. Faulkner et al. (1989) also reported an increase in beef flavor intensity for cull cows that were fed a concentrate diet for $42 \mathrm{~d}$, but found off-flavor was not affected as time on feed increased. Cranwell et al. (1996a) also reported an increase in beef intensity flavor at $28 \mathrm{~d}$ on feed, but no further increases in flavor intensity were seen as cull cows were fed longer.

Muscle differences in sensory overall tenderness (Table 5) did not follow the trends found by the WBS values. Although PSO was identified as the most tender muscle, it was similar $(P=0.23)$ in overall tenderness to TEM. The INF was the third most tender muscle as identified by sensory panelists. The LON, REF, TFL, LAT, and LOD were all similar $(P>0.14)$ and rated as slightly tender by sensory panelists. Similar to WBS values, the GM was rated the least tender muscle with an overall rating of slightly tough. Few differences were noted among muscles for sensory beef intensity flavor. All muscles were similar $(P>0.06)$ for beef flavor intensity except the INF, which was significantly lower $(P<$ 0.01) than all other muscles.

Dryden et al. (1979) found no difference in flavor intensity for the main effects of muscles or diet for cull cows that were realimented. The LAT was rated by sensory panelists as having the most off-flavor (slight off-flavor) and was similar $(P>0.06)$ to the PSO and $\mathrm{GM}$, both rated on the borderline of slight off-flavor and threshold off-flavor. The REF, TFL, and LON had the least off-flavor, whereas the LOD, INF, and TEM were scored as having threshold levels of off-flavor by the sensory panelists. However, it must be taken into consideration that approximately half of the samples tested for the LAT, PSO, and GM were scored as having no off-flavor, which masked the intensity of the samples with strong off-flavors when the data were pooled.

This research indicates that although cull cows commercially identified as being fed a high energy ration before slaughter are not similar to A-maturity USDA Select carcasses, they do show improvements over cull cows that are commercially identified as nonfed. Carcasses from supplemented beef and dairy cows had 
more desirable carcass characteristics than did cull beef cows that were not perceived to be supplemented before slaughter. As well, cull cows of the beef and dairy types that were identified as fed had increased carcass quality and produced more weight in lean than cull cows identified as nonfed. Cull cows identified as fed had a decreased incidence of off-flavor detection and had several muscles similar to or more tender than the LOD muscle. These muscles could be used in value added systems to fill a need for intermediately priced beef steaks that are still palatable to the consumer. More research is warranted to examine consumer satisfaction.

\section{LITERATURE CITED}

Aberle, E. D., E. S. Reeves, M. D. Judge, R. E. Hunsley, and T. W. Perry. 1981. Palatability and muscle characteristics of cattle with controlled weight gain: Time on a high energy diet. J. Anim. Sci. 52:757-763.

AMSA. 1995. Research Guidelines for Cookery, Sensory Evaluation, and Instrumental Tenderness Measurements of Fresh Meat. Am. Meat Sci. Assoc., Chicago, IL.

Bailey, A. J., and M. Shimokomaki. 1971. Age-related changes in the reducible crosslinks of collagen. FEBS Lett. 16:86-88.

Bidner, T. D., R. E. Montgomery, C. P. Bagley, and K. W. McMillin. 1985. Influence of electrical stimulation, blade tenderization and postmortem vacuum aging upon the acceptability of beef finished on forage or grain. J. Anim. Sci. 61:584-589.

Boleman, S. J., R. K. Miller, M. J. Buyck, H. R. Cross, and J. W. Savell. 1996. Influence of realimentation of mature cows on maturity, color, collagen solubility, and sensory characteristics. J. Anim. Sci. 74:2187-2194.

Brown, W. F., and D. D. Johnson. 1991. Effects of energy and protein supplementation of ammoniated tropical grass hay on the growth and carcass characteristics of cull cows. J. Anim. Sci. 69:348-357.

Cranwell, C. D., J. A. Unruh, J. R. Brethour, and D. D. Simms. 1996a. Influence of steroid implants and concentrate feeding on carcass and longissimus muscle sensory and collagen characteristics of cull beef cows. J. Anim. Sci. 74:1777-1783.

Cranwell, C. D., J. A. Unruh, J. R. Brethour, D. D. Simms, and R. E. Campbell. 1996b. Influence of steroid implants and concentrate feeding on performance and carcass composition of cull beef cows. J. Anim. Sci. 74:1770-1776.

Dryden, F. D., J. A. Marchello, A. Tinsley, C. B. Martins, R. A. Wooten, C. B. Roubicek, and R. S. Swingle. 1979. Acceptability of selected muscles from poor condition and realimented cull range cows. J. Food Sci. 44:1058-1062.

Faulkner, D. B., F. K. McKeith, L. L. Berger, D. J. Kesler, and D. F. Parrett. 1989. Effect of testosterone propionate on performance and carcass characteristics of heifers and cows. J. Anim. Sci. 67:1907-1915.

French, P., E. G. O'Riordan, F. J. Monahan, P. J. Caffrey, M. Vidal, M. T. Mooney, D. J. Troy, and A. P. Moloney. 2000. Meat quality of steers finished on autumn grass, grass silage or concentratebased diets. Meat Sci. 56:173-180.

Herring, H. K., R. G. Cassens, and E. J. Briskey. 1967. Factors affecting collagen solubility in bovine muscles. J. Food Sci. 32:534-538.

Hill, F. 1966. The solubility of intramuscular collagen in meat animals of various ages. J. Food Sci. 31:161-166.

Johnson, D. D., and A. L. Rogers. 1997. Predicting the yield and composition of mature cow carcasses. J. Anim. Sci. 75:18311836.

Matulis, R. J., F. K. McKeith, D. B. Faulkner, L. L. Berger, and P. George. 1987. Growth and carcass characteristics of cull cows after different times-on-feed. J. Anim. Sci. 65:669-674.

Miller, M. F., H. R. Cross, J. D. Crouse, and T. G. Jenkins. 1987. Effect of feed energy intake on collagen characteristics and muscle quality of mature cows. Meat Sci. 21:287-294.

Mink, L. E. 2004. Properties of cow and beef muscles: Benchmarking the differences and similarities. MS Thesis, Univ. Nebraska, Lincoln.

MLC. 2002. Beef carcass authentication service leaflet. Meat and Livestock Commission, Milton Keynes, UK. http://store.mlc.org.uk/index.asp?50479 Accessed Oct. 2, 2003.

Sawyer, J. E., C. P. Mathis, and B. Davis. 2004. Effects of feeding strategy and age on live animal performance, carcass characteristics, and economics of short-term feeding programs for culled beef cows. J. Anim. Sci. 82:3646-3653.

Schaake, S. L., G. C. Skelley, E. Halpin, L. W. Grimes, R. B. Brown, D. L. Cross, and C. E. Thompson. 1993. Carcass and meat sensory traits of steers finished on fescue and clover, summer forage, or for different periods in drylot. J. Anim. Sci. 71:3199-3205.

Strachan, D. B., A. Yang, and R. D. Dillon. 1993. Effect of grain feeding on fat colour and other carcass characteristics in previously grass-fed Bos indicus steers. Aust. J. Exp. Agric. 33:269-273.

USDA. 2005. Livestock slaughter-2004 summary. USDA, Natl. Agric. Stat. Serv., Washington, DC.

Yang, A., T. W. Larsen, and R. K. Tume. 1992. Carotenoid and retinol concentrations in serum, adipose tissue and liver and carotenoid transport in sheep, goats and cattle. Aust. J. Agric. Res. 43:1809-1817. 